\title{
An unusual foreign body in the eye
}

\author{
Damien Chia Ming Yeo
}

Department of Ophthalmology, Singleton Hospital, Swansea, UK

\section{Correspondence to} Dr Damien Chia Ming Yeo, cm.yeo@doctors.org.uk

\section{DESCRIPTION}

Foreign bodies in the eye can often lodge itself in the adnexae of the eye and not just in the cornea. A thorough history and examination can often aid in detecting these usually non-obvious materials.

A 56-year-old woman presented with an acute red eye of a day's duration. She was having persistent discomfort and pain in her eye. She had been initially seen by her general practitioner who was unable to locate a foreign body on the cornea.

History revealed that she had a haircut earlier that day after which her symptoms started. Slit-lamp examination showed that a tiny cut hair end had lodged itself in the upper lacrimal punctum. This was removed with a forceps. No other ocular trauma was noted.

Although eyelashes have been known to trap itself in lacrimal punctums, ${ }^{12}$ this was a short hair

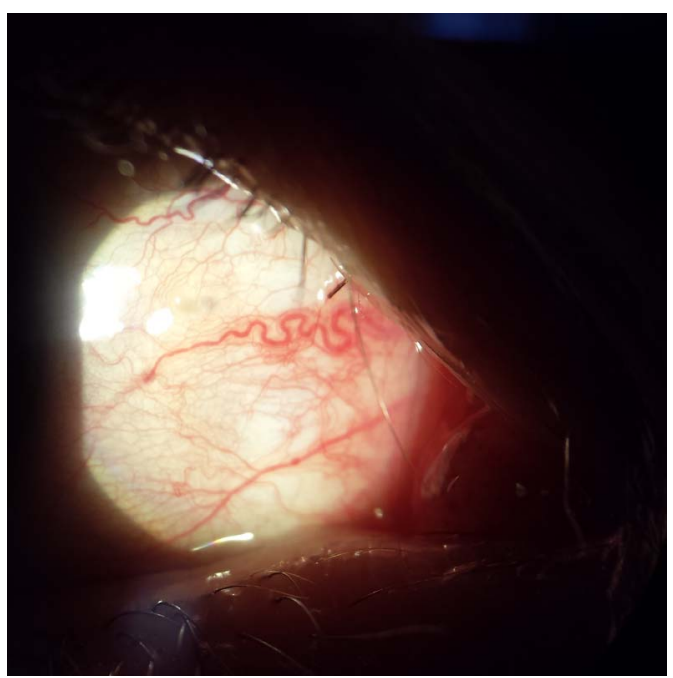

Figure 1 Trapped hair clearly seen in the right upper punctum. Hair looks more rigid than neighbouring eyelashes. Conjunctival injection inferior to the hair can also be seen. fragment from the scalp that was thicker and more rigid in structure. Tears naturally wash out foreign debris but in this scenario, the hair end got caught up in the lacrimal flow and the negative pressure created with each blink cycle ${ }^{3}$ likely drew the hair in (figure 1).

From the history we were able to be more specific in our examination and on everting the upper lid, an embedded hair end was clearly seen in the right upper punctum. This was removed fairly easily with immediate relief to the patient and also with much clinician satisfaction.

\section{Learning points}

- A careful history will aid in characterising the type of foreign body that we are looking for.

- Foreign bodies can be hiding in the adnexae of the eye and a thorough slit-lamp examination is important.

- Hair from the scalp is rigid and sharp and can cause a lot more discomfort than a trapped eyelash in the eye.

Acknowledgements With thanks to Dr Ameera Brett for assisting with the photograph

Competing interests None.

Patient consent Obtained.

Provenance and peer review Not commissioned; externally peer reviewed.

\section{REFERENCES}

1 Boase A. Eye-lash in the lacrimal punctum. Br J Ophthalmol 1949:513.

2 Meel R, Vashisht S. Eyelash in lacrimal punctum. DJO 2013;23:227.

3 Gutteridge IF. Curious cilia cases. Clin Exp Optom 2002;85:306-8. 
Copyright 2013 BMJ Publishing Group. All rights reserved. For permission to reuse any of this content visit http://group.bmj.com/group/rights-licensing/permissions.

BMJ Case Report Fellows may re-use this article for personal use and teaching without any further permission.

Become a Fellow of BMJ Case Reports today and you can:

- Submit as many cases as you like

- Enjoy fast sympathetic peer review and rapid publication of accepted articles

- Access all the published articles

- Re-use any of the published material for personal use and teaching without further permission

For information on Institutional Fellowships contact consortiasales@bmjgroup.com

Visit casereports.bmj.com for more articles like this and to become a Fellow 